Список литературы

1. Домбровский А., Хубицкий 3., Подковельный П., Робенс Э. (2004) Выборочное удаление ионы тяжелых металлов из вод и промышленных сточных вод ионообменным методом, Chemosphere, Vol. 56, c. 91-106.

2. Нуреддин С., Лехмичи А., Мубарак М.С. Сорбционные свойства иминодиацетатной ионообменной смолы, Amberlite İRC-718, по отношению к ионам двухвалентных металлов // J. Appl. Polym. Science, 2008, vol. 107, № 5, c. 13161319

3. Лин Л., Хуанг Р. Ионообменная кинетика $\mathrm{Cu}$ (II) и $\mathrm{Zn}$ (II) из водных растворов с двумя хелатообразующими смолами // Chemical Engineering Journal, 2007, vol. 132, № 1-2, с. 337-343

4. Хроматография. Продукты для анализа и очистки / sigma-aldrich.com / supelco 2003/2004, $453 \mathrm{c}$.

5. Шварценбах Г., Флашка $Г$.

Комплексонометрическое титрование. Москва:Химия, 1970, 360с.

6. Бойд Г.Е., Адамсон А.В., Майерс Л.С. Обменная адсорбция ионов из водных растворов органическими цеолитами. II. Кинетика // J. Аm. Химреагент Soc., 1947, vol. 69, № 11, с. 2836-

7. Баррер Р. М., Варфоломей Р. Ф. и Риз Л. В. C. / J.J.Phys. Химреагент Солидс, 1961, т. 12, с.21 (журнальная статья).

8. Гласстон С., Лейдлер К., Айринг Х. Теория процессов скорости. Н. Й. и Лондон, 1941, Принстонский университет, с. 501.

9. Фрейндлих Х.М.Ф. Die адсорбции в Lösungen. Z Phys Chem. 1906, 57, 385-470.

10. Редлич О., Петерсон Д.Л. Полезная изотерма поглощения // J. Phys. Chem., 1959, vol. 63, № 6, c. 1024-1026

\title{
SYNTHESIS, PROPERTIES OF METHACRYLOILETHYL-N, N - DIMETHYLALLYLAMMONIUMBROMIDE AND METHACRYLOILETHYL-N, N - DIMETHYLMETHYLENECARBOXYIAMMONIUMIODIDE
}

\section{ABSTRACT}

The possibility of realization of adjustable in a complex-radical polymerizationsynthesized monomer was shown on the basis of methacryloilethyl-N, N -dimethylallylammoniumbromide (MEDAAB) and methacryloilethyl-N, N -dimethylmethylenecarboxyiammoniumiodide (MEDMAI) at presence initiator persulfat calyx (PC) at moderate temperatures (283-293K). Synthesized polymeric in the water environment possess strongly pronounced surface-active properties, essentially reducing a superficial tension of water, show bactericidal abilities and define energy of adhesion and cohesion of the modifier on a surface of natural fibres, improve wettability of a fibre, critical concentration micelleformation.

Keywords: Cationic surface-active substances, critical concentration micelle formation (CCM), adsorption, wettability, energy of adhesion and cohesion, a superficial tension, sensitivity to microorganisms, hydrophilic and hydrophobic balance (HLB).

\section{INTRODUCTION}

Despite presence research ${ }^{1-3}$, devoted to questions of synthesis of polymer methods of the spontaneous, usually-radical and photoinitiatedpolymerization, based on high-volume processes, a question on a finding of more accessible methods of their synthesis, allowing to carry out reactions at rather low temperatures, to prevent course of undesirable collateral processes, is an actual problem in modern colloid chemistry.

However, in the literature results of researches and the mechanism of reaction of synthesis and polymerisationmonomeasuredquaternaryammonium the bases are discussed, reactions of spontaneous polymerization are studied and established thezwitter-ionic mechanism of polymerisationquaternaryammoniumsalts on the basis of interaction reaction haloidcontainingmonomers with amino compounds, and researches on the in a complex-radical polymerization based on the donor-acceptorinitiation ofaliphatic and aromatic tertiaryaminewith haloidalkyl at moderate temperatures, were not spent till now.

\section{EXPERIMENTAL}

Crystal salts of monomer synthesised interaction reaction of metacryloilethyl-N, N -dialkilamin with haloidalkyl (allilbromideor monoiodaceticacid) as follows: in a conic flask placed 1 moldimethylaminoethylmethacrylate (DMAEMA), $30 \mathrm{ml}$ of absolute acetone and added on drops 1 molhaloidcontaining connections, white crystals of salt dropped out in 3-4 hours. A flask with the received salts placed in a refrigerator for 2-3 days for brimfulldeposition crystal salts. The received salts blastic from a solution of absolute acetone and ethanol in the ratio 9:1. The synthesised crystal salts, are dissolved in water and organic solvents.

As a result of interaction reaction, for example, metacryloilethyl-N, N -dimethylamine with 3brompropen-1crystal salt methacryloilethyl-N, N -di- 
methylallylammoniumbromideis formed, metacriloilethyl-N, $\mathrm{N}$-diethylamine with $\alpha$-iodacetic acid forms crystal salt of methacryloilethyl-N, N -dimethylmethylenecarboxyiammoniumiodide.

In the IR-spectr of crystal salt of methacryloilethyl-N, N -dimethylmethylenecarboxyiammoniumiodide the intensive wide strip in the field of 3200-3600 $\mathrm{sm}^{-1}$, characteristic to valency fluctuation associatedhydroxyl to group $\mathrm{O} \geq \mathrm{C}-\mathrm{OH}$, valency fluctuations
$>\mathrm{C}=\mathrm{O}$ the groups connected with double communication at $3100 \mathrm{sm}^{-1}$, an absorption strip ${ }^{+} \mathrm{N}-\mathrm{CH}_{2}-$ groups in the field of 2800-2900 sm $\mathrm{sm}^{-1}$, valency fluctuations $\geq \mathrm{C}=\mathrm{O}$ carbonyl groups of carboxyl is observed at 1720 $\mathrm{sm}^{-1}$, valency fluctuations of carbonyl groups having interface to double communication in area of $1630 \mathrm{sm}^{-}$ 1 , valency fluctuations $\geq \mathrm{C}-\mathrm{O}-\mathrm{C} \leq$ communications at $1150 \mathrm{sm}^{-1}$ deformation fluctuations dimethyl groups $\mathrm{N}\left(\mathrm{CH}_{3}\right)_{2}$ at $1380 \mathrm{sm}^{-1}$ (fig. 1).

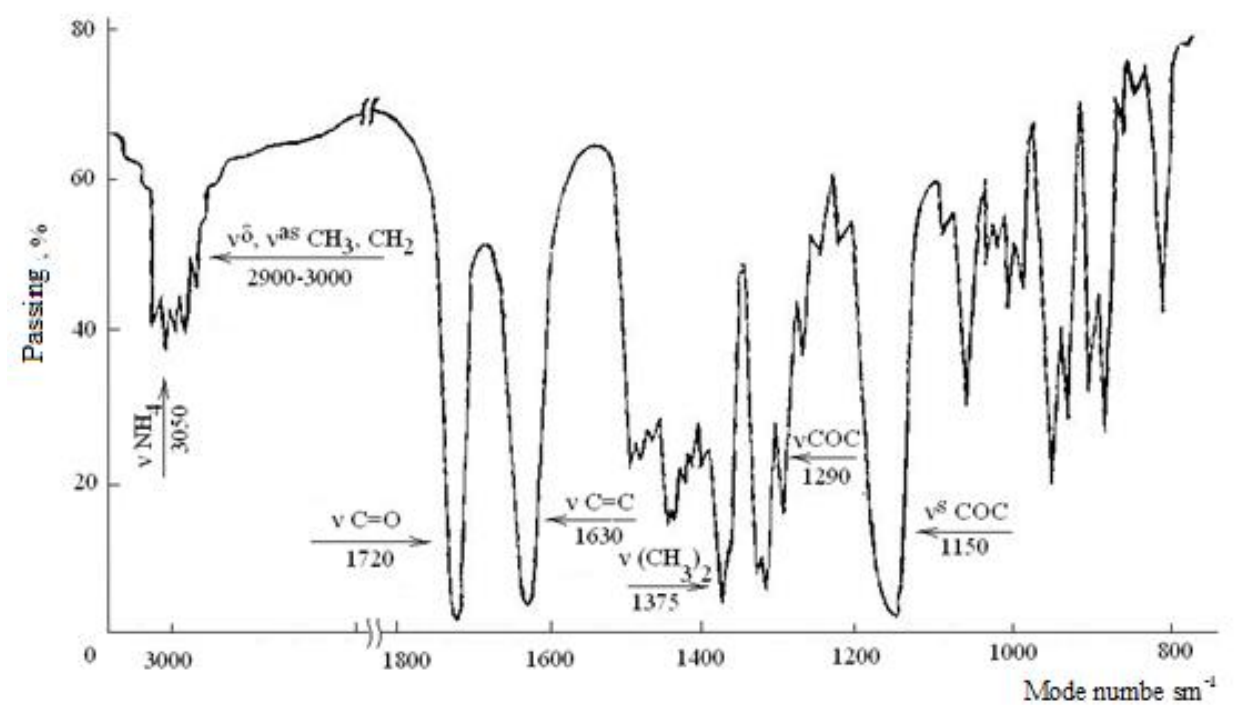

Fig. 1. IR-spectr crystal quaternary salts on the basis of methacryloilethyl- $N, N$ - dimethylmethylenecarboxyiammoniumiodide.

The structure of crystal salt of PMR-spectris also confirmed. In the PMR-spectrin the field of 5,76-6,30 m.p. Are observedtwo signals corresponding to nonequivalent protons $=\mathrm{CH}_{2}$, connected with double communication. In the field of 4,6-is observedthe signal of protons -O- $\mathrm{CH}_{2}$ - groups; at 4,0 m.p. it is shown triplet a signal concerning to $-\mathrm{N}^{+}-\mathrm{CH}_{2}$ - group; signal $-\mathrm{N}\left(\mathrm{CH}_{3}\right)_{2}$ gruppy, is observed in the field of 3,4 m.p.; the protons of group connected with carboxyl by an ion through methylen of group in the field of 3,0 m.p.; methyl the protons connected with carbon because of equivalent character are observed in a kind,singlet at 2,0 m.p. (Fig. 2).

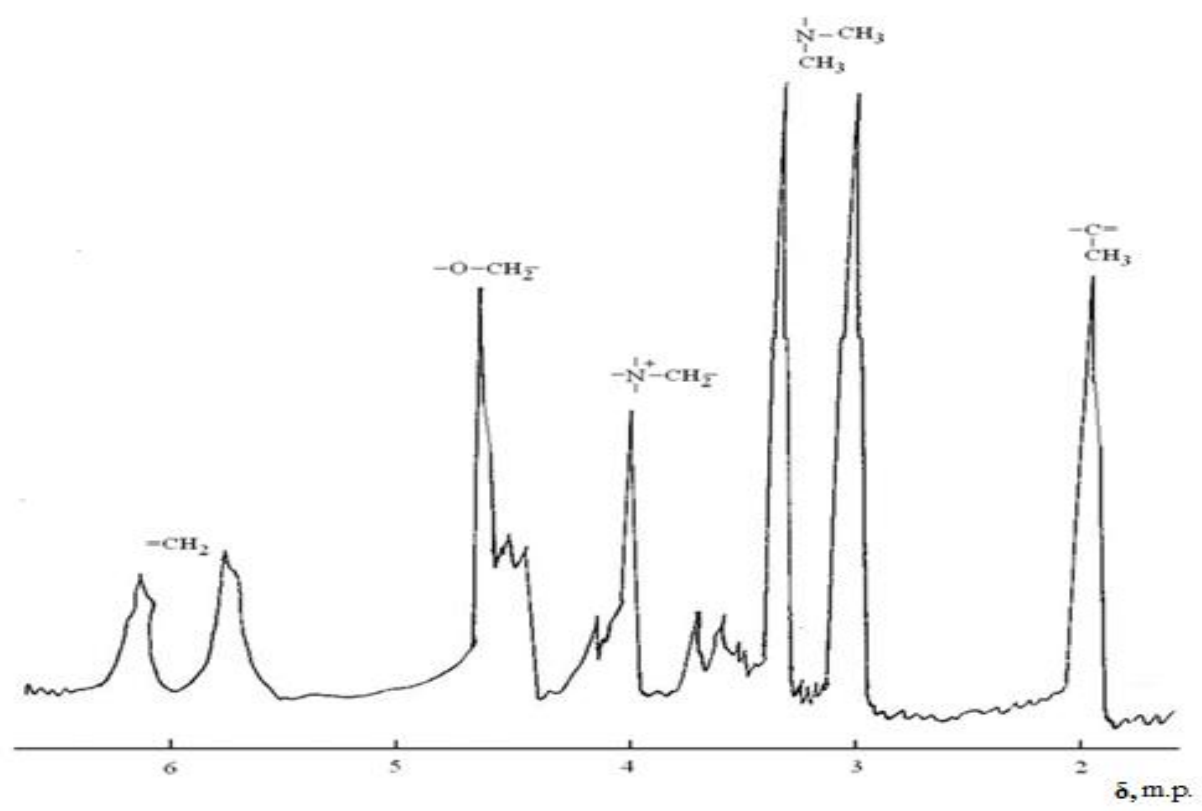

Fig. 2. PMR-spectr crystal quaternary salts on the basis of methacryloilethyl - N, N-dimethylmethylenecarboxyiammoniumiodide 
Kinetic of polymerizations by a was investigated dilatometric method. A superficial tension was investigated by the control over a blanket condition on border a solution - air by measurement of a superficial tension of a solution in static conditions. Definition of critical concentration micelle formation was carried out on isotherms of a superficial tension.

Measurements of a superficial tension allow to estimate superficial activity of monomer and to calculate according to the thermodynamic equation of Gibbs superficial surplus of the dissolved substance (adsorption) and the area occupied in sated adsorption a layer. Bactericidal action of monomer estimated on diameter of suppression of growth of various fungi and bacteria. A method forded ermination wettability based on definition of a regional corner wetting of the drop put on the moistened surface.

\section{RESULTS AND DISCUSSION}

In work for the first time have experimentally established that synthesised low-molecular monomer methacryloilethyl-N, N-dimethylallylammoniumbromide and methacryloilethyl - N, N - dimethylmethylenecarboxyiammoniumiodidein the water environment in the presence of the initiator of the personal computer, and also in the environment of organic solvents in the presence of initiators peroxidebenzoyl and dinitrilazobisizooil acids at temperatures 283-293K, initiators excluding thermal disintegration, polymerization with formation high-molecular polymer. ${ }^{4-7}$
Have experimentally established that low-molecular monomer on the basis of methacryloilethyl-N, Ndimethylallylammoniumbromidepolymerization in the presence of the initiator - persulfat calyx in the water environment. Defined a reaction order on a monomeasure $(0,5-2,0 \mathrm{~mol} / \mathrm{l})$ and to the initiator $(1,10$ $3 \div 5 \cdot 10-3 \mathrm{~mol} / \mathrm{l}$ ) which has appeared, accordingly, equal 1,48 and 0,5 . The overestimated value of an order of reaction on a monomeasure, in comparison with theoretical which is equal 1,0 , specifies in its participation not only in reaction of growth of a chain, but also in reaction of formation of the molecular complex which disintegration produces initiating centres. Speed of polymerization grows with temperature and its dependence on return value of temperature (in an interval 283298K) submits to the equation of Arrenius, energy of activation makes $53,7 \mathrm{kDj} / \mathrm{mol}$.

For the purpose of reception of some thermodynamic parametrescharacterising an end-product on an example of interaction methacryloilethyl-N, N-dimethylallylammoniumbromidewith persulfat calyxin water the balance constant $\left(\mathrm{K}_{\mathrm{r}}\right)$ reactions comlexcformation and factor of molar extinction of $(\varepsilon)$ a complex by the graphic decision of the equation of Beneshi-Hildebranda (tab. 1) has been defined.

Apparently from given tab. 1, the factor of molar extinction a complex practically does not depend on temperature, and the constant of balance of reactioncomlexformationeven $(283-293 \mathrm{~K})$ grows in a narrow temperature interval with rise in temperature.

Tab. 1.Value of factor molyrecstins $(\varepsilon)$ and balance constants $\left(\mathrm{K}_{\mathrm{r}}\right)$ at different temperatures

\begin{tabular}{|c|c|c|}
\hline $\mathrm{T}, \mathrm{K}$ & $\varepsilon, \mathrm{L} / \mathrm{mol} \cdot \mathrm{sm}$ & $\mathrm{K}_{\mathrm{r}}, \mathrm{L} / \mathrm{mol}$ \\
\hline 283 & 829 & 0,04 \\
\hline 288 & 834 & 0,09 \\
\hline 293 & 830 & 0,15 \\
\hline
\end{tabular}

From temperature dependence of a constant of balance of reaction of formation of a complex thermodynamic parametres of process comlexcreating- warmth of formation of a complex $(\Delta \mathrm{H})$, sizes of change of energy of Gibbs $(\Delta G)$ and entropy $(\Delta S)$ (tab. 2) have been defined. Values of thermodynamic parameters testify to stability of a complex.

Tab. 2.

Thermodynamic characteristics process of formation in a complex of methacryloilethyl-N, N-dimethylallilammoniumbromidewith persulfat calyx in thewater environment

\begin{tabular}{|c|c|c|}
\hline$-\Delta \mathrm{H}, \mathrm{kDj} / \mathrm{mol}$ & $-\Delta \mathrm{S}, \mathrm{Dj} / \mathrm{mol}$ & $-\Delta \mathrm{G}, \mathrm{kDj} / \mathrm{mol}$ \\
\hline 9,02 & 30,7 & 0,14 \\
\hline
\end{tabular}

Similar results have been received for process of polymerization monomeasured of monomer -methacryloilethyl-N, N-dimethylmethylencarboxyiammonyiodide, methacryloilethyl-N, N-dimethylpropylammoniumbromide.

In work results of research of physical and chemical properties synthesisedcationicSAS, colloid-chemical properties of their solutions, in particular are resulted: the superficial tension, moistening, sensitivity to some microorganisms, critical concentration micelle formation, influences on process of adhesion and cohesion, are calculated value gidrofilno-lipofilnogo balans. ${ }^{8-15}$

Processing of natural fibres by solutions of monomer on the basis of methacryloilethyl-N, N-dimethylpropylammoniumbromide considerably reduces a corner of their wetting by water, i.e. improves wettability of their surface water. ${ }^{14}$ Regional corners of wetting of the modified natural fibres depending on concentration of solutions modifying monomer are resulted on fig. 3. 


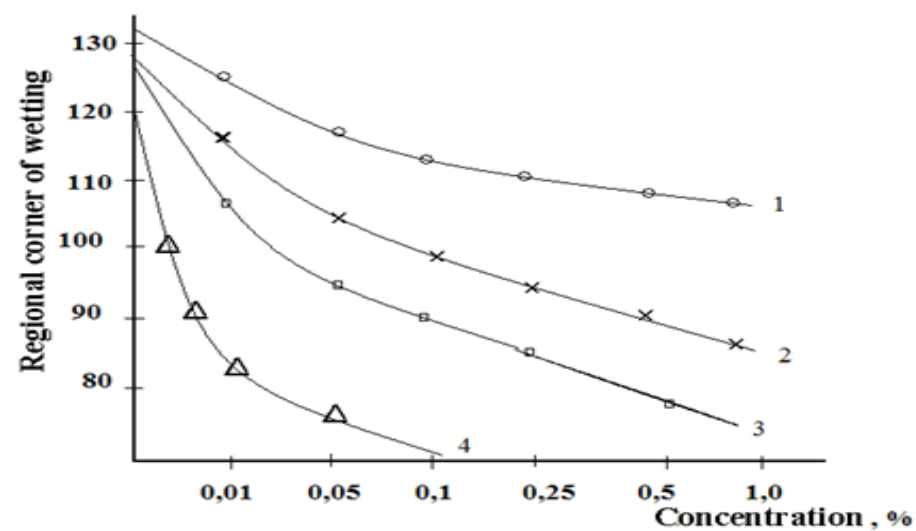

Fig. 3. Dependence of a regional corner of wetting by water of albuminous of fibres from concentration of solutions of modifying monomer: methacryloilethyl $-N, N$ - dimethylallylammoniumbromide (1), cetylpyridinechloride (2), dupanol (3), oxyethylizedalkulphenol.

Efficiency of action of solutions synthesised highmolecular polymer on the basis of MEDAAB on wettability of a fibre was compared by water to similar effect of action of solutions of low-molecular monomer: cationic-cetylpyridinechloride (CPC), anion- dupanol (DP) and nonionic-oxyethylizedalkylphenol.

Monomer methacryloilethyl-N, N - dimethylallylammoniumbromide and cetylpuridinechloride possess the big superficial activity in comparison with dupanol and oxyethlized polystyrene and considerably influence on intermolecular of cohesion liquid interaction. With the growth of concentration of the monomer, having small superficial activity, energy of its adhesion increases. Extreme dependence of energy of adhesion weed - methacryloilethyl $\square \square-\mathrm{N}, \quad \mathrm{N}$ dimethylallylammoniumbromide from concentration of the second it is possible to explain saturation of a surface of fibres with molecules of monomer.

Dependence of a superficial tension of water solutions of the synthesized substances on their concentration by a method of the greatest pressure of vials on $\mathrm{Re}$ binder (fig. 4) is defined. The facts show that investi- gating substances possess considerable superficial activity. However, higher superficial activity is observed at synthesized cationic surface-active substance on the basis of methacryloilethyl-N, N - dimethylallylammoniumbromide in comparison with other superficially active substances, such, as cetylpuridinechlaride, dupanol and oxyethylizedalkylphenol. This results from the fact that at synthesized cationic surface-active substance on the basis of methacryloilethyl-N, N - dimethylallylammoniumbromide the double communications which presence promotes increase of an index of polarity contain. Sites of excesses at an exit of isotherms on a plateau correspond to critical concentration mycellocreating. It is visible that rather strong superficial activity of polymeron the basis of methacryloilethyl-N, N - dimethylallylammoniumbromide in comparison with cetylpuridinechloride, dupanol, oxyethlizedalkylphenol (fig. 4) possesses. On the basis of experimental data of a superficial tension of solutions of the considered of monomer measured at their various concentration, have been calculated energy of cohesion molecules in solvent and adhesion of monomer on albuminousfibres.

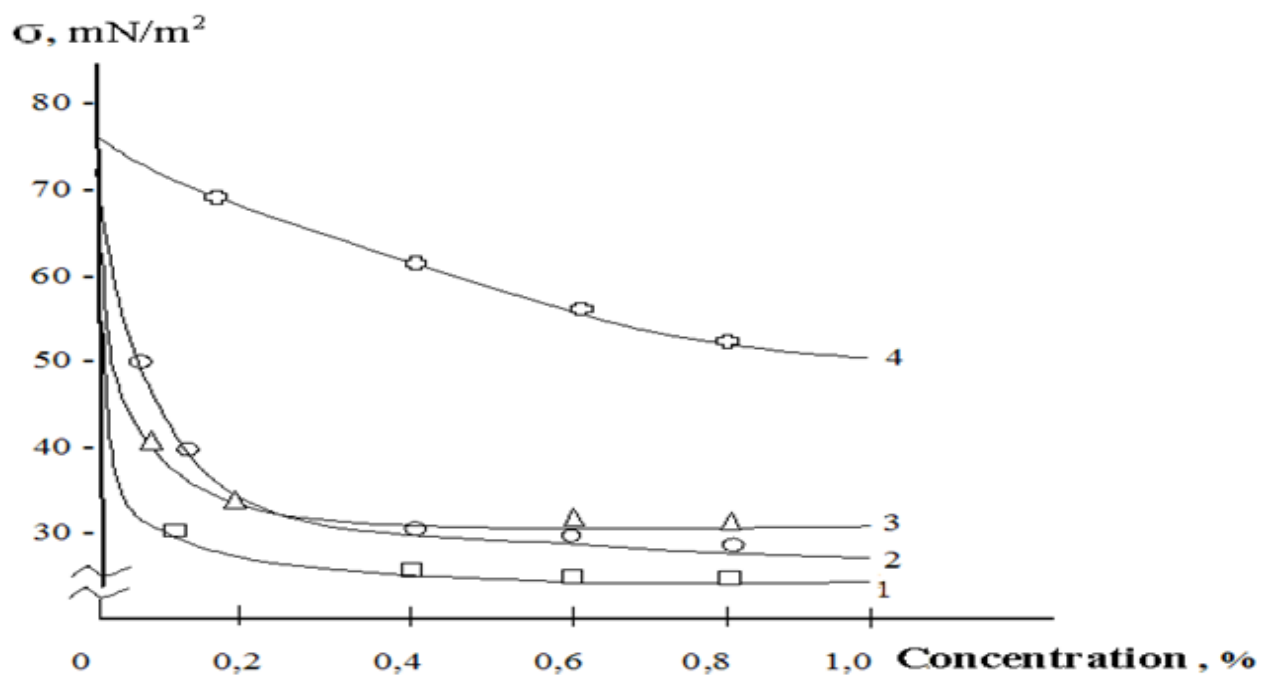

Fig. 4. Dependence of superficial on-tension of solutions of monomer from concentration: 1-methacryloilethyl$\mathrm{N}, \mathrm{N}$-dimethylallylammoniunbromidebromide, 2-cetylpuridinechlaride, 3-dupanol, 4-oxyethlized alkylphenol. 
Settlement values of energy of cohesion $\left(\mathrm{W}_{\mathrm{k}}\right)$ and adhesions $\left(\mathrm{W}_{\mathrm{a}}\right)$ are resulted in tab. 3. Under the resulted fact law is accurately traced that cetylpuridinechlaridic possesses rather smaller superficial activity, than polymerMEDAAB and influences on cohesiove inter- molecular interaction of a liquid owing to what its presence at a solution not strongly reduces energy of cohesion of solvent molecules. The greatest most strongly influences energy of cohesion of polymer on the basis of methacryloilethyl-N, N-dimethylallylammoniunbromide, possessing superficial activity.

Tab. 3.

Dependence of values of energy of cohesion $\left(\mathrm{W}_{\mathrm{k}}\right)$ and adhesions $\left(\mathrm{W}_{\mathrm{a}}\right)$ solutions surface-active substances from their concentration

\begin{tabular}{|c|c|c|c|c|c|c|c|c|}
\hline Concentrationof & \multicolumn{2}{|c|}{ Polymer MEDAAB } & \multicolumn{2}{|c|}{ SPC } & \multicolumn{2}{c|}{ DP } & \multicolumn{2}{c|}{ OP } \\
\cline { 2 - 9 } monomer, \% & $\mathrm{W}_{\mathrm{k}}$ & $\mathrm{W}_{\mathrm{a}}$ & $\mathrm{W}_{\mathrm{k}}$ & $\mathrm{W}_{\mathrm{a}}$ & $\mathrm{W}_{\mathrm{k}}$ & $\mathrm{W}_{\mathrm{a}}$ & $\mathrm{W}_{\mathrm{k}}$ & $\mathrm{W}_{\mathrm{a}}$ \\
\hline 0,01 & 140,6 & 26,0 & 120,8 & 25,0 & 111,8 & 31,4 & 111,1 & 30,7 \\
\hline 0,025 & 140,0 & 31,8 & 94,8 & 26,6 & 101,8 & 31,8 & 87,1 & 38,3 \\
\hline 0,05 & 138,0 & 43,2 & 79,4 & 27,4 & 89,8 & 37,9 & 80,7 & 42,1 \\
\hline 0,10 & 129,0 & 50,0 & 69,6 & 31,8 & 82,2 & 43,9 & 79,4 & 44,6 \\
\hline 0,50 & 114,6 & 55,3 & 66,8 & 35,7 & 74,2 & 43,5 & 74,6 & 43,9 \\
\hline
\end{tabular}

The greatest most strongly influences energy of cohesion of polymeron the basis of methacryloilethyl$\mathrm{N}, \mathrm{N}$-dimethylallylammoniunbromide, possessing superficial activity.

Application of chemical compounds with various degree of biological activity can lead to balance infringement in the surrounding nature, to occurrence of sharp and chronic poisonings of live organisms, their change immunobiological reaction, increase of level of the general disease and working capacity decrease. ${ }^{16} \mathrm{~A}$ particular interest among chemical compounds represent monomeasured and polymeric of monomer. It is necessary to notice that at laboratory diagnostics of data on a poisoning with chemical reactants, especially sensitivity of some microorganisms to the last are extremely limited and inconsistent. Considering the given circumstance, sensitivity of some microorganisms to low - and high-molecular cationic to surface-active substances on the basis of methacryloilethyl-N, N - dymethylmethylenecarboxyiammonyiodide and methacryloilethyl-N, N - dimethylallylammoniun has been studied.

Results of the spent researches have shown that cultures staphylococcus, an intestinal stick, proteus and salmonellas are sensitive to all examinees of monomer and polymer. At the same time, it is interesting to notice that cultures yeast-like sort of mushrooms candidate have appeared tolerant to action of all considered monomer and polymer.

Repeated researches have convincingly shown that among the studied systems the greatest bacteriostatic and bacteriacidic effect possess monomer and polymeron the basis of methacryloilethyl-N, N - dimethylmethylenecarboxyiammoniuniodide. Thanks to iodine and bromine presence in the synthesized monomer and polymer at processing of textile fibres by them and materials on their basis, the last get antimicrobic properties.

Efficiency of surface-active substances characterise special number - hidrofilno-lipofilnym balance (HLB). The important characteristic of molecules colloidal the monomer, having crucial importance for their superficial and volume properties so, and for their ap- plication, the parity of two opposite groups of a molecule - hydrophilic and waterproof (lipophilic) is, socalled gidrofilno-lipofilnyj balance. ${ }^{17,18}$

It is necessary to notice that HLB is the important quantitative characteristic colloidal the monomer, connected with their various application.

On the basis of given values HLB hydrophilic groups and lipophilic groups under Griffin's offered formula values HLB synthesized monomer are calculated. Calculated value of HLB for monomer methacryloilethyl- $\mathrm{N}, \mathrm{N}$-dimethylmethylenecarboxiumiammonyiodide makes: HLB $=9,23,8+7=12,4$; and for methacryloilethyl-N, N - dimetilallilammoniumbromide - HLB $=16,24,75+7=18,45$, numbers HLB are linearly connected by superficial activity. This parametre underlies characteristics of properties of monomer and in practice till now usually quality of monomer estimate on numbers HLB. Received values HLB correspond to process accompanied solubilization water solutions, from this it follows that superficial activity of monomer defines their ability to lower a superficial tension, to cause foaming, wetting etc. Calculated values of HLB testify to use monomer as surface-active modifiers for improvement of properties of textile fibres.

\section{CONCLUSION}

For reception cationic polymer with the set properties are improved known and new ways of complexradical polymerization activated donor- acceptoringby interaction cationic monomer with acceptors electrons - initiators of polymerization are developed at the temperatures excluding thermal disintegration of initiators.

Synthesized polymer in the water environment possess strongly pronounced surface-active properties, essentially reducing a superficial tension of water, show bactericidal abilities and define energy of adhesion and cohesion the modifier on a surface of natural fibres, improve wettability of a fibre, water solutions are characterised inherent in them electroconductivity of, viscosity, critical concentration mycellocreating.

Acknowledgments. This work has been supported basic researches and programs of development of a science of the Tashkent institute textile and light industry (01870007180). Thanks for financial support of Committee of development of a science and technol- 
ogy of Uzbekistan (K6-012). Thanks for financial support of Committee of development of a science and technology of Uzbekistan (F7-FK-0-10324-F7-001).

\section{References}

1. Wei Zhou, Li-Hui Tang, Ke-Qiang Ma, Fang Li. Synthesis and Properties of a Polymerizable Quaternary Ammonium Salt // Journal of Applied Polymer Science. 131(21). 2014.

2. Zhang, J., Tan, W., Luan, F., Yin, X., Dong, F., Li, Q., Guo, Z. Synthesis of Quaternary Ammonium Salts of Chitosan Bearing Halogenated Acetate for Antifungal and Antibacterial Activities // Polymers. 2018, 10, 530.

3. Ruziev R.R., Maksumova A.S., Djalilov A.T., Topchiev D.A. Proceedings of IHE. Chemistry and chemical technology. 1986, 29, 23.

4. Ismailov R.I., Maksumova A.S., Askarov M.A. Proceedings of IHE. Chemistry and chemical technology. 1993, 117.

5. Synthesis and Mechanism of the Preparation of Polymeric Cationic Surface-Active Substances // International journal of chemical and physical sciences, India, 2015, Volume 4, Number 2, P.93-98.

6. Hartmann, L, Gorbatschow, W, Hauwede, $\mathrm{J} \&$ Kremer, F. Molecular dynamics in thin films of isotactic poly(methyl methacrylate) // Eur. Phys. J. E. 8, 145-154. 2002.

7. Isa G. J. de Avellar, Kênia Godoy and Gouvan C. de Magalhães. New quaternary ammonium salts de- rived from cardanol and their use as phase transfer catalyst // Journal of the Brazilian Chemical Society. 2000. Universidade de Brasília, 70.910-900.

8. OleaA.F., GamboaC. Colloid and Interface Sci. 2003, 257, 321.

9. Langevin D. Advances in Colloid and Interface Science. 2009, 147, 170 .

10. McLoughlin D., Langevin D. Colloids and Surf.2004, 250, 79 .

11. Gamboa C., Olea A.F. Colloids and Surf. 2006, 278, 241.

12. Koopal L.K., Goloub T.P., Davis T.A. Colloid and Interface Sci. 2004, 275, 360.

13. Fainerman V.B., Kovalchuk V.I., Aksenenko E.V., Michel M., Leser M.E., Miller R. Phys. Chem. B. 2004, 108, 13700.

14. Fainerman V.B., Zholob S.A., Leser M.E., Michel M., Miller R. Phys. Chem. B. 2004, 108, 16780.

15. RusakovA.I. Micelle formation in solutions of surface-active substances. Sankt-Petersburg.Chemistry.1992, 237.

16. IsmailovR.I., NigmatovaF.U., AskarovM.A. Fibre chemistry. 2012, 43, 441.

17. Tulegenova G.U., Adilbekova A.O., Musabekov K.B. XVII th European Chemistry at interfaces conference. London, 2005, 57.

18. Musabekov K.B., Tazhibaeva S.M., Sapieva A.O. The $16^{\text {th }}$ Intern.Symp. OnSurfactantsin Solutions. Seoul, 2006, 51.

\title{
OBTAINING DETERGENTS FOR TECHNICAL PURPOSES BASED ON «SUPER-ALKALI»
} AND ACTIVE ADDITIVES

\author{
Kaipbergenov Atabek Tulepbergenovich, \\ Doctor of Technical Science \\ Nukus State Pedagogical Institute, \\ Karajanova Shakhnoza Daryabaevna- \\ student. \\ Nukus State Pedagogical Institute, \\ DOI: 10.31618/ESU.2413-9335.2019.2.59.53-55
}

\section{Abstract}

The optimal formulations of technical cleaners are determined. Experimental data of the article allow us to conclude that alkaline solutions containing surfactants contribute to the removal of oily stains, since under their action fats are «saponified».

Keywords: super-alkali, surfactant, sodium metasilicate, ammonium polyphosphate, ammonium monophosphate, detergents and cleaning products, alkaline.

Today in the world, the use of modern technologies in acceleration of the development of industry, the solution of environmental problems, the production of competitive and environmentally friendly substances is becoming an actual problem. In recent years, on the basis of new developments, innovative approaches, there has been an increase in the production of products necessary for industry.

One of the main directions of economic development of Uzbekistan is the development of natural resources, their integrated use and the creation of competitive import-substituting products based on local raw materials. The chemical industry is the base industry, which is in close relationship with all sectors of the economy. Therefore, the development of the chemical industry is a priority task for the modern development of the economy of the Republic of Uzbekistan. One of the chemical products is powdered detergents (PD), the need for which is steadily increasing due to the development of industries of the national economy that consume detergents. The market for detergents and cleaning products includes the following segments of the market of household chemical goods: synthetic detergents (SD), bleaches and products that complement the action of laundry detergent, as well as cleaning products.

The effectiveness of a detergent and the quality of cleaning a metal surface largely depends on the properties of the treated surface - its roughness, sensitivity to the corrosive effect of the detergent, the presence of oxides on the surface, its homogeneity [1]. 